VOL. 3

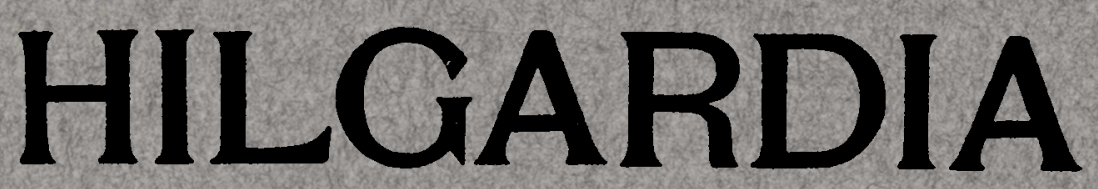

A Journal of Agricultural Science

PUBLISHED BY THB

California Agricultural Experiment Station

\title{
CONTENTS
}

Relation of Tuber Maturity and of Storage Factors

to Potato Dormancy

and

\section{Effects of Chemical Treatments on Dormant Potato Tubers}

J. T. ROSA 


\section{EDITORIAL BOARD}

E. D. MERRILL, Sc.D.

J. T. Barrett, Ph. D.

Plant Pathology

F. T. Bioletti, M.S.

Viticulture

W. H. Chandler, Ph.D.

Pomology

R. E. Clausen, Ph.D.

Genetics

H. E. Erdman, Ph.D. Agricultural Economics

H. M. Evans, A.B., M.D. Nutrition

G. H. Hart, M.D., D.V.M. Veterinary Science

D. R. Hoagland, M.S.

Plant Nutrition

A. H. Hoffman, E. E. Agricultural Engineering
W. L. Howard, Ph. D.

Pomology

H. A. Jones, Ph. D.

Truck Crops

W. P. Kelley, Ph, D.

Chemistry

W. A. Lippincott, Ph.D.

Poultry Husbandry

C. S. Mudge, Ph.D.

Bacteriology

H. J. Quayle, M.S.

Entomology

H. S. Reed, Ph.D.

Plant Physiology

W. W. Robbins, Ph.D.

Botany

F. J. Veihmeyer, Ph.D.

Irrigation 


\section{EFFECTS OF CHEMICAL TREATMENTS ON DORMANT POTATO TUBERS}

J. T. ROSA 1

Foreword

The treatment of dormant tubers with various substances to hasten sprouting has been extensively investigated, but as yet no method of treatment has been adopted by commercial growers. While it is believed that such matters as tuber maturity, storage temperature, and the normal length of dormant period for the variety are important factors, the use of chemical stimulants for seed treatment is also likely to be of practical value in many cases. The word "stimulant" is used to designate substances which are probably not used as nutrients, yet are capable of accelerating the plants' activities.

In this paper will be presented the results of a number of experiments, designed largely to determine effective methods for the stimulation of sprouting in dormant seed potatoes. Studies concerning the effect of such treatments upon the metabolism of the tuber are under way, but the discussion of this phase of the work will not be entered upon at this time.

\section{Previous Work with Chemical Treatments}

McCallum $^{(4)}$ found that sprouting was hastened by exposing potatoes to the fumes of ethyl bromide, carbon tetrachloride, ammonia, and gasoline, at the rate of $1 / 2$ to 1 cc. in a 5 -liter chamber for 24 hours. He also obtained positive results with ethyl bromide and with ethylene chloride. Appleman ${ }^{(1)}$ found that treatment with hydrogen peroxide gave positive results. Rosa ${ }^{(5)}$ has reported hastened sprouting by soaking the cut sets in solutions of various salts before planting ; 0.5 molar solutions of sodium and potassium nitrates for periods ranging from 10 minutes to one hour, $0.02 \mathrm{~mol}$. potassium permanganate, $.005 \mathrm{~mol}$. ferric chloride, and .05 normal hydrochloric acid for

${ }^{1}$ Assistant Professor of Truck Crops and Associate Plant Breeder in the Experiment Station. 
one hour, were all found to hasten sprouting, especially when the tubers were in the middle or later part of their dormant period. However, these materials were found to be somewhat toxic to the tissues of the tubers. While this had no bad effects when the sets were planted in fall, winter, or spring, when soil temperatures were low, there did result an increased amount of seed piece decay when the planting was in mid-summer, with high soil temperatures prevailing. Denny ${ }^{(2)}$ tested 224 different chemicals on potatoes. He obtained striking results in hastened sprouting with ethylene chlorhydrin and ethylene dichloride applied in various way, and with sodium, potassium, and ammonium thiocyanate solutions. Even dormant tubers of the Irish Cobbler variety were caused to sprout in one month after planting by treatment with 2 or 3 per cent solutions of the thiocyanates. Denny also obtained favorable results with carbon bisulfide and some other substances.

Three varieties, White Rose, Idaho Rural, and Irish Cobbler, have been used in the writer's experiments. Tubers were grown at Davis in the regular spring crop, harvested just before the plants died, and placed in storage at $22^{\circ}$ to $23^{\circ} \mathrm{C}$. The storage period in most cases was three to four weeks. Plantings were made in sand in the coldframe, and in soil in the field. Counts were made every few days of the sprouts, as they emerged above the surface of the soil.

\section{EXPERIMENTS with ETHYLENE}

In 1925, two experiments were carried out, to determine the effect of ethylene gas on germination of potatoes. In the first test, three varieties were used. The tubers were harvested June 20, when they were approaching maturity. They were stored in a dry cellar at about $22^{\circ}$ C. The samples to be treated for four weeks were placed in the gas chambers on June 24 and treatment was continued until July 23. The samples to be treated for two and three weeks were held in the cellar with the checks until the proper date, and then removed to the gas chamber. On July 26 ( 36 days after harvest) the tubers were cut and planted in the coldframe. The chambers were about 400 liters capacity, and were not absolutely airtight. Sufficient ethylene gas was applied each day to give a concentration of $1: 400$ in one chamber and $1: 2200$ in the other. The chambers were opened for a few minutes each day for ventilation. As the results with the two concentrations paralleled each other, they are averaged in table 1. 
With these three varieties, 4 weeks' treatment with ethylene resulted in more rapid sprouting than was the case with the untreated checks. The difference was slight with the White Rose variety, which apparently had nearly reached the end of its dormant period (having been held at $22^{\circ}$ for 36 days). The lots exposed to ethylene for 3 and 2 weeks gave in every case a slower rate of germination than the checks. The reason for this fact may be the known toxicity of ethylene to vegetative growth, as the sprouts may have started slightly on the 2- and 3-week lots before they were placed in ethylene. These lots were held in the cellar for 1 and 2 weeks, respectively, before

TABLE 1

EFfect of Ethylene UPON Sprouting. July-September, 1925

\begin{tabular}{c|c|c|c|c}
\hline Treatment & $\begin{array}{c}\text { Number } \\
\text { of sets }\end{array}$ & $\begin{array}{c}\text { Per cent } \\
\text { stand }\end{array}$ & $\begin{array}{c}\text { Average } \\
\text { number of } \\
\text { days to } \\
\text { emerge }\end{array}$ & $\begin{array}{c}\text { Average } \\
\text { number of } \\
\text { stems } \\
\text { per set }\end{array}$ \\
\hline White Rose & & & & \\
Ethylene, 4 weeks & 60 & 95.0 & 28.3 & 1.51 \\
Ethylene, 3 weeks & 60 & 93.4 & 39.6 & 1.38 \\
Ethylene, 2 weeks & 60 & 95.0 & 39.0 & 1.28 \\
Untreated & 90 & 84.5 & 30.8 & 1.20 \\
Idaho Rural & & & & \\
Ethylene, 4 weeks & 60 & 75.0 & 22.2 & 1.18 \\
Ethylene, 3 weeks & 60 & 76.6 & 38.9 & 1.15 \\
Ethylene, 2 weeks & 65 & 87.7 & 43.4 & 1.09 \\
Untreated & 90 & 74.7 & 30.7 & 1.12 \\
Irish Cobblers & & & & \\
Ethylene, 4 weeks & 29 & 93.2 & 42.0 & 1.30 \\
Ethylene, 3 weeks & 30 & 93.2 & 70.5 & 1.14 \\
Ethylene, 2 weeks & 29 & 86.3 & 56.8 & 1.12 \\
Untreated & 60 & 73.4 & 50.0 & 1.23 \\
\hline
\end{tabular}

being placed in the gas chamber. All of the ethylene-treated lots gave a higher percentage of stand than the checks, and a slight increase in the average number of stems arising from each set.

A second experiment with ethylene was performed in the fall of 1925, fully matured, spring crop tubers harvested July 30 being used. Lots of 30 to 40 sets each were planted in the greenhouse at intervals after harvesting. The untreated tubers were stored at $20^{\circ}$ to $23^{\circ} \mathrm{C}$, while those treated with ethylene were kept at the same temperature in a chamber with ethylene at 1:800 concentration applied daily. The results are given in table 2.

With the White Rose variety, the plantings made after 6 and 15 days show a marked hastening of the sprouting of tubers exposed to ethylene. The later plantings showed little difference, however, as the 
tubers had evidently passed their dormant period. In this case, fully mature tubers of a variety having only a short dormant period were involved. With the Idaho Rural, the ethylene-treated lots sprouted more rapidly at all stages, though the gain over the untreated checks was greatest at the 15 and 28-day periods. In all cases, there was a tendency for the number of stems per set to increase as the period between harvest and planting was lengthened. This was most marked with the lots stored in ethylene gas. Rosa ${ }^{(5)}$ has previously called

TABLE 2

Effect of Ethylene upon Sprouting, with Reference to the Stage of

Dormancy. Fall, 1925

\begin{tabular}{|c|c|c|c|c|c|c|}
\hline \multirow[b]{2}{*}{. } & \multicolumn{3}{|c|}{ Untreated } & \multicolumn{3}{|c|}{ Ethylene 1:800 } \\
\hline & $\begin{array}{l}\text { Per cent } \\
\text { stand }\end{array}$ & $\begin{array}{c}\text { Average } \\
\text { number of } \\
\text { days to } \\
\text { emerge }\end{array}$ & $\begin{array}{c}\text { Average } \\
\text { number of } \\
\text { stems } \\
\text { per set }\end{array}$ & $\begin{array}{l}\text { Per cent } \\
\text { stand }\end{array}$ & $\begin{array}{c}\text { Average } \\
\text { number of } \\
\text { days to } \\
\text { emerge }\end{array}$ & $\begin{array}{c}\text { Average } \\
\text { number of } \\
\text { stems } \\
\text { per set }\end{array}$ \\
\hline \multicolumn{7}{|l|}{$\begin{array}{l}\text { White Rose } \\
\text { Planted after }\end{array}$} \\
\hline $\begin{array}{l}\text { Planted after } \\
6 \text { days' storage }\end{array}$ & 67 & 55.9 & 1.00 & 100 & 36.9 & 1.07 \\
\hline 15 days' storage. & 77 & 38.2 & 1.14 & 97 & 33.2 & 1.00 \\
\hline 28 days' storage & 100 & 20.0 & 1.04 & 100 & 20.5 & 1.03 \\
\hline 39 days' storage & 100 & 18.2 & 1.23 & 100 & 17.0 & 1.36 \\
\hline 55 days' storage & 100 & 21.2 & 1.17 & 100 & 17.0 & 1.58 \\
\hline \multicolumn{7}{|l|}{ Idaho Rural } \\
\hline 6 days' storage & 63 & 773 & 100 & 90 & 71.4 & 1.00 \\
\hline 15 days' storage & 45 & 60.8 & 1.00 & 83 & 29.5 & 1.21 \\
\hline 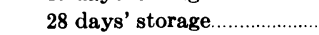 & 100 & 38.4 & 1.03 & 100 & 27.1 & 1.14 \\
\hline 39 days' storage & 100 & 30.2 & 1.17 & 100 & 22.0 & 1.21 \\
\hline 55 days' storage & 100 & 29.7 & 1.23 & 100 & 16.5 & 1.61 \\
\hline
\end{tabular}

attention to the increase in number of stems, in potatoes planted after the end of the dormant period, compared to those which are still somewhat dormant.

\section{Experiments with Ethylene Chlorhydrin on Large Tubers}

This substance is obtained commercially as a 40 per cent solution of the gas in water. The gas volatilizes rather slowly when the solution is exposed to air. It was used in the three ways suggested by Denny. (1) Fumigating whole tubers in a closed chamber for 24 hours, using 1 cubic centimeter to each liter of space in the chamber. (2) Soaking cut sets in a one-half per cent solution for one hour. (3) Dipping the cut sets in a 3 per cent solution (or stronger) for a moment, then placing them in a closed container overnight. 
The tubers used in the 1926 tests were harvested June 19, in a slightly immature condition. They were stored at $23^{\circ} \mathrm{C}$ until July 13, a period of 24 days, except for the four lots which were treated and planted 14 days after harvest. The tubers should have been still in the dormant condition at the end of this period. The results are given in table 3 .

\section{TABLE 3}

Effect of Ethylene Chlorhydrin upon Sprouting of Cut Sets From Large Mature Tubers. Summer, 1926

\begin{tabular}{|c|c|c|c|c|c|c|}
\hline & \multicolumn{3}{|c|}{ Coldframe plantings } & \multicolumn{3}{|c|}{ Field plantings } \\
\hline & $\begin{array}{c}\text { Num- } \\
\text { ber of } \\
\text { sets }\end{array}$ & $\begin{array}{c}\text { Per } \\
\text { cent } \\
\text { stand }\end{array}$ & $\begin{array}{c}\text { Average } \\
\text { number } \\
\text { of days } \\
\text { to } \\
\text { emerge }\end{array}$ & $\begin{array}{c}\text { Num- } \\
\text { ber of } \\
\text { sets }\end{array}$ & $\begin{array}{c}\text { Per } \\
\text { cent } \\
\text { stand }\end{array}$ & $\begin{array}{c}\text { Average } \\
\text { number } \\
\text { of days } \\
\text { to } \\
\text { emerge }\end{array}$ \\
\hline \multicolumn{7}{|l|}{$\begin{array}{l}\text { White Rose, planted } 14 \text { days after harvest. } \\
\text { Lot No. }\end{array}$} \\
\hline 52. Untreated. & 60 & 77.4 & 47.8 & 0 & .......... & .......... \\
\hline 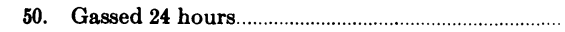 & 30 & 80.5 & 27.5 & 0 & .......... & ......... \\
\hline 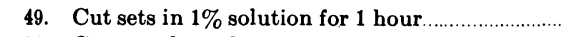 & 30 & 66.6 & 37.5 & 0 & .......... & .......... \\
\hline 51. Cut sets dipped in $3 \%$ solution & 30 & 19.3 & 41.8 & 0 & ............... & (n............. \\
\hline \multicolumn{7}{|l|}{ White Rose, planted 24 days after harvest. } \\
\hline 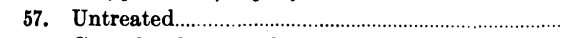 & 60 & 74.9 & 34.3 & 241 & 50.6 & 38.5 \\
\hline 55. Gassed 24 hours at harvest time & 30 & 73.4 & 24.4 & 43 & 46.5 & 30.1 \\
\hline 53. Gassed 24 hours 2 weeks after harvest & 30 & 70.0 & 23.9 & 82 & 72.0 & 26.8 \\
\hline 61. Gassed 24 hours at planting time & 30 & 86.6 & 20.9 & 98 & 49.0 & 39.4 \\
\hline $60 \mathrm{~A}$. Cut sets in $1 / 2 \%$ solution for 1 hour & 30 & 86.6 & 25.6 & 76 & 53 & 31.8 \\
\hline $60 \mathrm{~B}$. Same solution as in $60 \mathrm{~A}$, second lot $\ldots \ldots \ldots \ldots \ldots \ldots$ & 30 & 83.2 & 23.2 & 0 & .......... & .......... \\
\hline 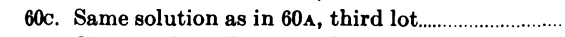 & 30 & 66.6 & 21.6 & $\mathbf{0}$ & .......... & .......... \\
\hline 63. Cut sets dipped in $3 \%$ solution & 30 & 30.0 & 19.6 & 69 & 36 & 34.8 \\
\hline 91. Cut sets dipped in $4 \frac{1}{2} \%$ solution & 0 & ......... & ......... & 94 & 24.5 & 39.5 \\
\hline \multicolumn{7}{|l|}{ Idaho Rural, planted 24 days after harvest. } \\
\hline 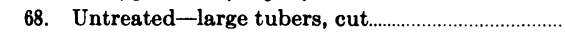 & 161 & 76.8 & 34.6 & 399 & 61.6 & 51.1 \\
\hline 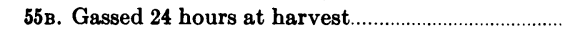 & 30 & 56.6 & 21.6 & 104 & 68.0 & 29.7 \\
\hline
\end{tabular}

The White Rose tubers treated and planted two weeks after harvest (lots 49, 50, and 51) showed marked hastening of sprouting, especially in lot 50, which was treated by method 1 . Those treated by method 3 , in a 3 per cent solution, were much injured.

Lots 55A, 53, and 61, planted 24 days after harvest, were medium to large tubers, treated according to method 1 just after harvesting, 2 weeks after harvesting, and just before planting. Denny suggested that the toxic effects of the treatment upon the tubers may be lessened by treating some days in advance of cutting and planting. The results in coldframe and field plantings do not agree entirely. In the former, the treatment was most effective when given just before planting, 
while in the field the highest percentage of stand and the most rapid sprouting occurred in the lot treated two weeks after harvest. It is apparent that the treatment at all three periods had considerable effect in hastening sprouting, with no evidence of toxic effects. It may be concluded that seed tubers can be safely treated at any time between harvest and planting. Figure 1 shows the marked difference

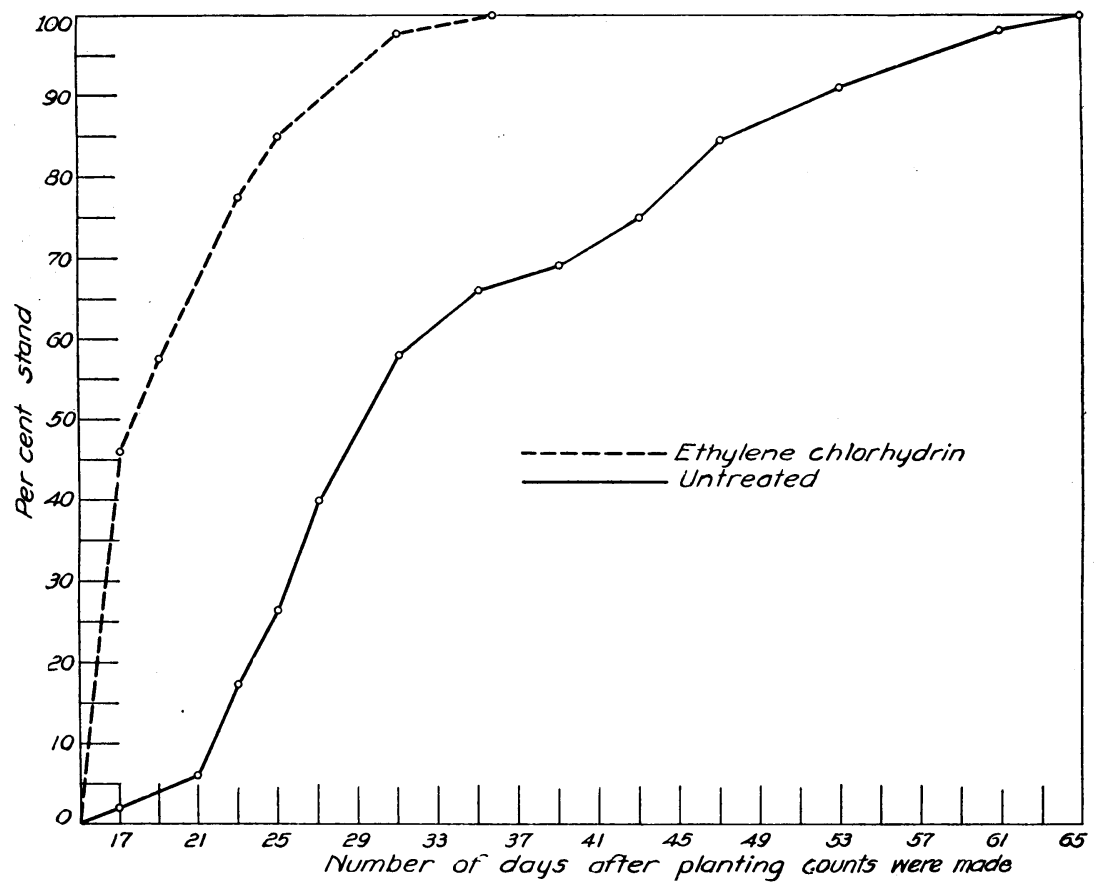

Fig. 1. The rate of sprout emergence of White Rose sets planted 24 days after harvest. Lot 57 , untreated, and lot 61 , treated with ethylene chlorhydrin just before planting, by method 1 .

in rate of sprout emergence between untreated sets and those treated with ethylene chlorhydrin at planting time by method 1 . While the treatments with ethylene chlorhydrin hasten sprouting, they do not, on the average, give a materially higher percentage of germination than no treatment, when cut sets from large tubers are considered. This is due, as in all the other experiments under high temperature conditions, to the decay of a large number of sets soon after planting.

With the Idaho Rural variety, large tubers treated with ethylene chlorhydrin at harvest time according to method 1 gave a very marked acceleration of sprouting, there being an average gain of 13 days in the coldframe planting and 31.4 days in the field planting. However, 
the percentage of the sets planted that produced plants was no larger than in the untreated lot.

Lots $60 \mathrm{~A}, 60 \mathrm{~B}$, and $60_{\mathrm{c}}$ were treated according to method 2 , the same solution being used to treat the three lots successively. The stimulation to sprouting was marked in all cases. Lots 63 and 91, treated according to method 3, again showed decided toxicity from this treatment, most of the seed pieces decaying.

On the whole, the results show that ethylene chlorhydrin is effective in hastening the sprouting of dormant potatoes, thus confirming

TABLE 4

Experiments with Ethylene Chlorhydrin used According to Method 1, on Large Tubers. Summer, 1927

\begin{tabular}{|c|c|c|c|c|c|c|}
\hline & \multicolumn{3}{|c|}{ Coldframe planting } & \multicolumn{3}{|c|}{ Field planting } \\
\hline & $\begin{array}{c}\text { Number } \\
\text { of sets }\end{array}$ & $\begin{array}{l}\text { Per cent } \\
\text { stand }\end{array}$ & $\begin{array}{c}\text { Average } \\
\text { number of } \\
\text { days to } \\
\text { emerge }\end{array}$ & $\begin{array}{l}\text { Number } \\
\text { of sets }\end{array}$ & $\begin{array}{l}\text { Per cent } \\
\text { stand }\end{array}$ & $\begin{array}{l}\text { Averag } \\
\text { number of } \\
\text { days to } \\
\text { emerge }\end{array}$ \\
\hline \multicolumn{7}{|l|}{ White Rose } \\
\hline Gassed 24 hours, 1 cc per liter............................. & 30 & 100. & 21.7 & 107 & 73.8 & 25.4 \\
\hline Gassed 24 hours, 0.75 cc per liter...................... & 30 & 86.6 & 21.1 & 114 & 73.7 & 23.8 \\
\hline 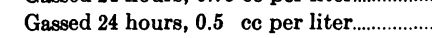 & 30 & 76.6 & 22.4 & 120 & 44.2 & 27.5 \\
\hline 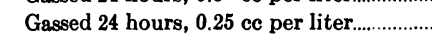 & 30 & 90.0 & 23.9 & 118 & 49.2 & 27.5 \\
\hline 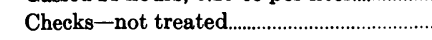 & 120 & 72.3 & 33.6 & 577 & 61.7 & 34.0 \\
\hline \multicolumn{7}{|l|}{ Idaho Rural } \\
\hline 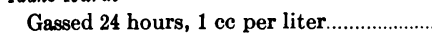 & 30 & 80.0 & 33.3 & 117 & 68.4 & 31.9 \\
\hline Gassed 24 hours, 0.75 cc per liter......................... & 30 & 83.3 & 29.4 & 107 & 59.8 & 30.9 \\
\hline Gassed 24 hours, 0.5 cc per liter.................. & 30 & 86.6 & 33.2 & 80 & 27.5 & 33.3 \\
\hline Gassed 24 hours, 0.25 cc per liter.......................... & 30 & 70.0 & 32.0 & 86 & 41.0 & 38.9 \\
\hline 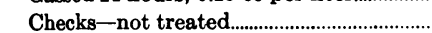 & 90 & 57.7 & 35.6 & 554 & 56.6 & 37.9 \\
\hline
\end{tabular}

Denny's work. However, treatment with this material does not prevent decay of the seed pieces under high temperature conditions, and in treatment by method 3, even increases it. This factor would probably not be so serious in cool localities or in winter and spring plantings. Of the various methods of using ethylene chlorhydrin, method 1 seems most likely to be suitable for commercial use.

Further experiments with ethylene chlorhydrin were conducted in 1927 , to determine the optimum concentration for treatment by method 1. A tight chamber, $4 \times 4 \times 5$ feet in size, was used. The tubers were placed in shallow boxes stacked one above the other with strips between. An electric fan blowing directly upon a pan containing the ethylene chlorhydrin hastened its volatization. The treatments were made at $20^{\circ}$ to $24^{\circ} \mathrm{C}$. Denny ${ }^{(3)}$ states that the dosage can be 
reduced to .35 cc. per liter of space, when the treatment is performed in such a room, with a fan. The results obtained on the large tubers treated by this method are given in table 4 . The treatments were made 10 or 11 days after harvesting upon tubers stored in a dry cellar at $22^{\circ} \mathrm{C}$. The tubers were cut and planted 10 days later.

The White Rose responds somewhat more markedly to treatment with ethylene chlorhydrin than does the Idaho Rural, but both varieties show a marked stimulation of sprouting from treatment with this material. The sprouting is most rapid with 1 ce. and with 0.75 ce. per liter of space, the latter concentration being slightly more effective than the former. The lower concentrations, while exerting considerable effect, are markedly less stimulating under the conditions of these experiments. There was no evidence of toxic effects at any concentration, the percentage of stand being in most cases better than that of the checks.

\section{Experiments with Ethylene Chlorhydrin upon Small Tubers}

Because so many cut sets decay when planted in the field during summer, and since uncut tubers are not so subject to decay, it was thought that it might be advisable, from the practical point of view, to plant small tubers whole. Earlier experiments, however, had shown that sets of this kind sprouted very slowly. Experiments were made in the summers of 1926 and 1927 to determine the effect of various chemical treatments on such tubers. The results with ethylene chlorhydrin are given in table 5. Tubers, harvested mature, about 1.5 ounces in average weight, were treated according to method 1 at harvest time and just before planting, respectively.

Treatment with ethylene chlorhydrin in most cases increased the per cent stand, as determined by the last count at the end of the growing season, but the speed of sprout emergence was increased only slightly. In the latter respect, however, the tests of 1927 with both White Rose and Idaho Rural show distinctly more marked effects from treatment immediately after harvest than from treatment in the middle of the storage period or just before planting. The lesser degree of suberization of the periderm at harvest time than after storage for a period, may permit the ethylene chlorhydrin to enter the tissues of the tuber more effectively. The fact remains, however, that small tubers planted whole do not respond vigorously to the same treatment that proved very effective on large tubers of the same varieties and 
degree of maturity, but which were cut before planting. Similar results were obtained with ethylene dichloride and ethyl bromide, and are shown graphically in figure 2. Cutting is itself a mild dormancybreaking treatment, as shown by Appleman. ${ }^{(1)}$ Schlumberger $^{(6)}$ considers wound-irritation, as induced by cutting the tuber or by injury in various other ways, to be of great importance in stimulation effects. Such effects are lacking when the tubers are planted whole.

TABLE 5

Experiments with Ethylene Chlorhydrin upon Sprouting of SMall Tubers Planted Whole, 21 Days after Harvest

\begin{tabular}{|c|c|c|c|c|c|c|}
\hline & \multicolumn{3}{|c|}{ Coldframe planting } & \multicolumn{3}{|c|}{ Field planting } \\
\hline & $\begin{array}{c}\text { Number } \\
\text { of sets }\end{array}$ & $\begin{array}{l}\text { Per cent } \\
\text { stand }\end{array}$ & $\begin{array}{c}\text { Average } \\
\text { numberof } \\
\text { days to } \\
\text { emerge }\end{array}$ & $\begin{array}{c}\text { Number } \\
\text { of sets }\end{array}$ & $\begin{array}{c}\text { Per cent } \\
\text { stand }\end{array}$ & $\begin{array}{c}\text { Average } \\
\text { number of } \\
\text { days to } \\
\text { emerge }\end{array}$ \\
\hline \multicolumn{7}{|l|}{ White Rose, 1926} \\
\hline Lot 56A. Gassed at harvest.... & 30 & 53.3 & 52.8 & 107 & 74.0 & 72.7 \\
\hline Lot 62. Gassed at planting ................ & 30 & 60.0 & 60.5 & 78 & 74.0 & 74.7 \\
\hline Lot 58. Check-not treated........................... & 30 & 13.3 & 64.7 & 85 & 42.0 & 81.4 \\
\hline \multicolumn{7}{|l|}{ White Rose, 1927} \\
\hline Lot 67. Gassed at harvest............................. & 0 & ......... & .......... & 102 & 90.0 & 43.4 \\
\hline 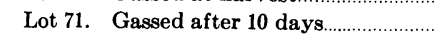 & 0 & ......... & .......... & 115 & 90.0 & 49.6 \\
\hline Lot 74. Gassed at planting ............ & 0 & …....... & ........... & 115 & 86.0 & 50.6 \\
\hline Lot 38. Check-untreated..... & 0 & .......... & .......... & 120 & 85.0 & 61.7 \\
\hline \multicolumn{7}{|l|}{ Idaho Rural, 1926} \\
\hline Lot 56в. Gassed at harvest & 30 & 56.6 & 52.4 & 98 & 85.0 & 70.9 \\
\hline Lot 56. Check-untreated............................... & 30 & 83.2 & 56.6 & 109 & 82.0 & 81.1 \\
\hline \multicolumn{7}{|l|}{ Idaho Rural, 1927} \\
\hline Lot 68. Gassed at harvest ............. & 0 & $\ldots \ldots \ldots$ & ......... & 117 & 71.8 & 52.8 \\
\hline 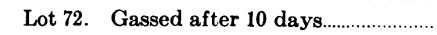 & 0 & ............... & $\ldots \ldots . . .$. & 120 & 83.3 & 61.5 \\
\hline Lot 75. Gassed at planting & 0 & ........... & ........... & 120 & 74.2 & 65.0 \\
\hline Lot 39. Check-untreated & 0 & .......... & ............ & 120 & 76.7 & 65.5 \\
\hline
\end{tabular}

\section{Experiments with Sodium Thiocyanate}

Denny ${ }^{(2)}$ reported favorable results from soaking cut sets for one hour in 3 per cent solutions of sodium thiocyanate, when the tubers were deeply dormant, and in a 2 per cent solution for one hour or in a 1 per cent for two hours, as they approached the end of the dormant period. Experiments were conducted in the summer of 1926 to determine the suitability of sodium thiocyanate for treatment of potatoes under California conditions. Ammonium thiocyanate was used in 1927. Large tubers of the White Rose variety, harvested quite immature, and smaller but mature tubers of the Idaho Rural and 
Irish Cobbler were used. The difference in maturity and in tuber size may explain the less injurious effects secured with the last two varieties. It has been the general observation in all of these experiments that seed piece decay is more prevalent in sets cut from large tubers, especially when they are harvested immature. Table 6 gives the results.

TABLE 6

Effect of Sodium Thiocyanate and Ammonium Thiocyanate upon Sprouting

\begin{tabular}{|c|c|c|c|c|c|c|}
\hline & \multicolumn{3}{|c|}{ Coldframe planting } & \multicolumn{3}{|c|}{ Field planting } \\
\hline & $\begin{array}{c}\text { Number } \\
\text { of sets }\end{array}$ & $\begin{array}{c}\text { Per cent } \\
\text { stand }\end{array}$ & $\begin{array}{c}\text { Average } \\
\text { number of } \\
\text { days to } \\
\text { emerge }\end{array}$ & $\begin{array}{c}\text { Number } \\
\text { of sets }\end{array}$ & $\begin{array}{l}\text { Per cent } \\
\text { stand }\end{array}$ & $\begin{array}{l}\text { Average } \\
\text { number of } \\
\text { days to } \\
\text { emerge }\end{array}$ \\
\hline $\begin{array}{l}\text { White Rose, } 3 \text { weeks after harvest. } \\
\text { Lot 57. Untreated. }\end{array}$ & 90 & 67.8 & 30.2 & 98 & 467 & 414 \\
\hline $\begin{array}{l}\text { Lot 37. } 2 \text { per cent solution of NaCNS for } \\
1 / 2 \text { hour }\end{array}$ & 30 & 70.0 & 35.4 & 89 & 50.6 & 35.3 \\
\hline $\begin{array}{c}\text { Lot 38. } 2 \text { per cent solution of } \mathrm{NaCNS} \text { for } \\
1 \text { hour }\end{array}$ & 30 & 66.6 & 33.0 & 105 & 63.8 & 34.8 \\
\hline Lot 39. Same, second lot............................. & . 30 & 32.0 & ......... & 0 & ......... & $\begin{array}{l}34.8 \\
\ldots \ldots \ldots .\end{array}$ \\
\hline Lot 40. Same, third lot................................. & 30 & 16.7 & $\ldots \ldots . .$. & 0 & ......... & .......... \\
\hline Lot 41. Same, fourth lot & 30 & 3.3 & ......... & 0 & ......... & .......... \\
\hline $\begin{array}{l}\text { Lot } 42.3 \text { per cent solution of } \mathrm{NaCNS} \text { for } \\
1 / 2 \text { hour }\end{array}$ & 30 & 26.7 & 28.7 & 106 & 46.2 & 36.8 \\
\hline 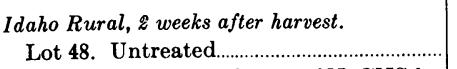 & 30 & 90.6 & 45.8 & 0 & 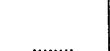 & 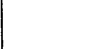 \\
\hline 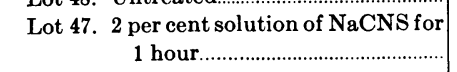 & 30 & 74.2 & 43.6 & 0 & .......... & .......... \\
\hline $\begin{array}{l}\text { Idaho Rural, } 8 \text { weeks after harvest. } \\
\text { Lot } 67 \text {. Untreated. }\end{array}$ & 161 & 76.8 & 34.6 & 399 & 61.6 & 51.1 \\
\hline 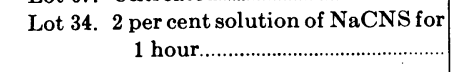 & 30 & 76.6 & 28.5 & 116 & 77.6 & 32.3 \\
\hline 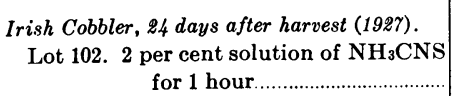 & 35 & 31.6 & 33.5 & 120 & 21.6 & 38.0 \\
\hline $\begin{array}{l}\text { Lot 103. } 2 \text { per cent solution of } \mathrm{NH}_{3} \mathrm{CNS} \\
\text { for } 1 / 2 \text { hour }\end{array}$ & 35 & 48.6 & 41.8 & 120 & 37.5 & 44.1 \\
\hline $\begin{array}{l}\text { Lot 104. } 1 \text { per cent solution of } \mathrm{NH}_{3} \mathrm{CNS} \\
\text { for } 1 \text { hour.................................... }\end{array}$ & 34 & 64.7 & 45.4 & 0 & & $\ldots \ldots .$. \\
\hline 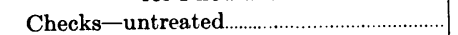 & 60 & 63.3 & 37.2 & 186 & 78.6 & 36.2 \\
\hline
\end{tabular}

Soaking the White Rose sets in 2 per cent sodium thiocyanate for one-half hour and for one hour had little effect upon the percentage of stand or upon the time required for sprouting. The Idaho Rural variety treated in a 2 per cent solution for one hour, two weeks after harvest, showed little effect, but this treatment a week later gave marked hastening of sprouting without toxic effects. Treatment in 3 per cent solution for only one-half hour resulted in very severe injury to the sets. With the Irish Cobbler, treatment in 2 per cent 
solutions of ammonium thiocyanate was very toxic, the amount of seed piece decay being much increased. The 1 per cent solution was not toxic, but had no effect upon the rate of sprouting. In other tests, in the greenhouse during the winter, the 3 per cent solution gave marked stimulation without toxic effects. With this material, as with others previously tested in California, the danger of toxic effects is greatly increased in hot weather. The thiocyanates, like some other substances, may be used safely in the cooler parts of the season, but cause much decay of the sets, with resultant poor stands, under high temperature conditions.

Lots 38,39 , and 41 , which were treated successively in the same solution, show a decreasing stand, indicating increased toxicity of the thiocyanate solution. This may be due to differential absorption of ions by the potato tissue, thus altering the composition of the solution. Apparently sodium thiocyanate solution cannot be used repeatedly in treating potatoes.

\section{Other Chemical Treatments}

Several chemicals besides those previously discussed have been tested from time to time, to determine their effect upon sprouting. Since time and concentration factors are involved, as well as the stage of dormancy of the tuber and the temperature at which the plantings are made, this is a slow and laborious process. In the winter of 1924-25, tests were made in the greenhouse of immature White Rose tubers of the fall crop harvested November 15 . Table 7 gives the results of some treatments which had positive results.

The immature tubers treated only 2 days after harvesting on November 17 showed marked stimulation by ethyl bromide. Whole tubers (which were cut before planting) of the stage of maturity used in these tests cannot be safely treated for more than 15 minutes at the concentration employed. Cut sets did not respond as well as those treated whole and then cut for planting. The time and concentration factors should both be much lower where cut sets are to be treated.

Potassium dichromate was mildly stimulating, but was toxic at the higher concentrations, the tissue around the eyes being chiefly affected, and not the pith parenchyma (inner medulla) as is the case with most toxic substances. Potassium ferro- and ferricyanide, tested at this time in concentrations ranging from $.05 \mathrm{~mol}$. to $.25 \mathrm{~mol}$. solutions for one hour, showed both forms of injury, and no stimulating effects. 
In the tests planted January 10, the tubers were nearing the end of the dormant period. Whole tubers were treated with the various materials, then cut and planted at once. Ethyl acetate and ether showed considerable stimulation, while carbon tetrachloride and gasoline had less effect. The last two substances, tested at higher concentrations, proved toxic. Chloroform was decidedly toxic, and

TABLE 7

Miscellaneous Chemical Treatments in Winter of 1924-25

\begin{tabular}{|c|c|c|c|c|}
\hline Date and treatment & $\begin{array}{l}\text { Number } \\
\text { of sets }\end{array}$ & $\begin{array}{l}\text { Per cent } \\
\text { stand }\end{array}$ & $\begin{array}{c}\text { Average } \\
\text { number of } \\
\text { days to } \\
\text { emerge }\end{array}$ & $\begin{array}{l}\text { Injury } \\
\text { to sets }\end{array}$ \\
\hline \multicolumn{5}{|l|}{$\begin{array}{l}\text { ov. 17. Ethyl bromide on whole tubers, cut for } \\
\text { planting. }\end{array}$} \\
\hline 4 cc per liter for 15 minutes & 19 & 84 & 31.4 & slight \\
\hline 4 ce per liter for 30 minutes & 20 & 60 & 31.4 & severe \\
\hline 4 cc per liter for 60 minutes & 17 & 35 & ......... & very severe \\
\hline Untreated & 35 & 90 & 92.0 & ........................ \\
\hline \multicolumn{5}{|l|}{ Ethyl bromide on cut sets. } \\
\hline 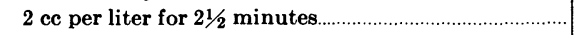 & 20 & 100 & 49.7 & none \\
\hline 2 cc per liter for 5 minutes & 19 & 100 & 43.8 & none \\
\hline 2 cc per liter for $71 / 2$ minutes & 19 & 95 & 54.2 & very slight \\
\hline 2 cc per liter for 10 minutes & 17 & 94 & 50.5 & slight \\
\hline 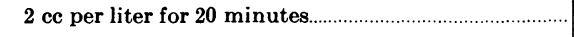 & 19 & 79 & 44.3 & severe \\
\hline \multicolumn{5}{|l|}{ Dec. 10. Potassium dichromate-cut sets. } \\
\hline Soaked 1 hour in .01 mol. solution & 18 & 67 & 59.5 & eyes injured \\
\hline Soaked 1 hour in $.005 \mathrm{~mol}$. solution & 17 & 88 & 66.9 & none \\
\hline Soaked 1 hour in .001 mol. solution & 17 & 100 & 53.4 & none \\
\hline Untreated & 36 & 100 & 70.0 & 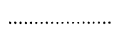 \\
\hline \multicolumn{5}{|l|}{ Jan. 10. Whole tubers, cut for planting. } \\
\hline 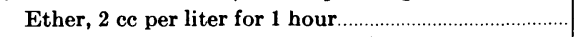 & 21 & 100 & 22.9 & none \\
\hline Ethyl acetate, 2 cc per litre for 1 hour & 20 & 100 & 21.4 & none \\
\hline Chloroform, 2 ce per liter for 1 hour & 17 & 47 & $\ldots \ldots . .$. & severe \\
\hline Carbon tetrachloride, 2 cc per liter for 1 hour & 18 & 100 & 25.1 & none \\
\hline Gasoline, 4 ce per liter for 1 hour & 17 & 100 & 25.2 & none \\
\hline Untreated & 21 & 100 & 29.4 & $\ldots \ldots \ldots \ldots \ldots . . .$. \\
\hline
\end{tabular}

bromine and chlorine gases, which were tested at one-half and at one hour exposures, were very toxic.

In the summer of 1925 , tests were made on tubers harvested nearly mature, the results of which are given in table 8 . Whole tubers were exposed to ethyl bromide for 15 minutes at the same concentration as before. This treatment, upon well suberized tubers after one month's storage gave little stimulation; the results were not so striking as in former tests, with immature tubers. Small tubers treated 10 days after harvest for 15,30 , and 60 minutes, and planted without cutting, showed very little stimulation with the time and concentration used 
TABLE 8

Effect of Miscellaneous Chemicals upon Sprouting. Summer, 1925

(Coldframe planting - 30 sets in each lot)

\begin{tabular}{|c|c|c|c|c|}
\hline & \multicolumn{2}{|c|}{ White Rose } & \multicolumn{2}{|c|}{ Idaho Rural } \\
\hline & $\begin{array}{l}\text { Per cent } \\
\text { stand }\end{array}$ & $\begin{array}{c}\text { Average } \\
\text { number of } \\
\text { days to } \\
\text { emerge }\end{array}$ & $\begin{array}{l}\text { Per cent } \\
\text { stand }\end{array}$ & $\begin{array}{c}\text { Average } \\
\text { number of } \\
\text { days to } \\
\text { emerge }\end{array}$ \\
\hline Large tubers 1 month after harvest. & \multirow{3}{*}{$\begin{array}{l}97 \\
84.5\end{array}$} & \multirow{3}{*}{$\begin{array}{l}27.8 \\
30.8\end{array}$} & \multirow{3}{*}{$\begin{array}{l}97 \\
72\end{array}$} & \multirow{3}{*}{$\begin{array}{l}\mathbf{4 4 . 0} \\
37.3\end{array}$} \\
\hline 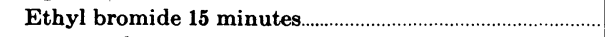 & & & & \\
\hline 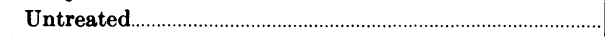 & & & & \\
\hline Small tubers 10 days after harvest. & \multirow{5}{*}{$\begin{array}{l}0 \\
0 \\
0 \\
0\end{array}$} & \multirow{3}{*}{$\ldots \ldots$} & \multirow[b]{2}{*}{97} & \multirow[b]{2}{*}{76.6} \\
\hline Ethyl bromide for 15 minutes. & & & & \\
\hline Ethyl bromide for 30 minutes & & & 80 & 71.0 \\
\hline Ethyl bromide for 60 minutes & & …...... & 82 & 70.9 \\
\hline 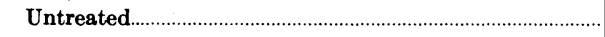 & & .......... & 93 & 80.0 \\
\hline \multicolumn{5}{|l|}{ Tubers 17 days after harvest-cut sets. } \\
\hline Sodium nitrate, .5 mol. solution, soaked 10 minutes...... & 90 & 21.0 & 77 & 31.2 \\
\hline Sodium nitrate, $.5 \mathrm{~mol}$. solution, soaked 20 minutes...... & 87 & 22.8 & 63 & 27.9 \\
\hline Sodium nitrate, .5 mol. solution, soaked 30 minutes...... & 63 & 25.5 & 27 & 27.0 \\
\hline Untreated & 84 & 33.5 & 90 & 55.7 \\
\hline Potassium permanganate, .02 mol. solution, soaked & 77 & 33.1 & 77 & 36.5 \\
\hline $\begin{array}{l}\text { Potassium permanganate, } .02 \mathrm{~mol} \text {. solution, soaked } \\
30 \text { minutes }\end{array}$ & 70 & 29.0 & 72 & 37.0 \\
\hline
\end{tabular}

here. Subsequent experiments with ethyl bromide, however, using 0.25 cc. to 0.5 cc. per liter for 24 hours upon whole tubers, gave a marked stimulation to sprouting, without toxic effects.

Treatment of cut sets 17 days after harvest in 0.5 mol. solution of sodium nitrate gave a marked stimulation to sprouting, especially in Idaho Rural variety. Under the high temperatures prevailing when these tests were made, even a 20 minute soaking in nitrate solution caused some injury, and a 30 minute one was very toxic. Potassium

TABLE 9

Effect of Miscellaneous Chemicals upon Sprouting. Summer, 1926

\begin{tabular}{|c|c|c|c|c|c|c|}
\hline & \multicolumn{3}{|c|}{ Coldframe plantings } & \multicolumn{3}{|c|}{ Field plantings } \\
\hline & $\begin{array}{l}\text { Num- } \\
\text { ber of } \\
\text { sets }\end{array}$ & $\begin{array}{c}\text { Per } \\
\text { cent } \\
\text { stand }\end{array}$ & $\begin{array}{c}\text { Average } \\
\text { number } \\
\text { of days } \\
\text { to } \\
\text { emerge }\end{array}$ & $\begin{array}{c}\text { Num- } \\
\text { ber of } \\
\text { sets }\end{array}$ & $\begin{array}{l}\text { Per } \\
\text { cent } \\
\text { stand }\end{array}$ & $\begin{array}{c}\text { Average } \\
\text { number } \\
\text { of days } \\
\text { to } \\
\text { emerge }\end{array}$ \\
\hline 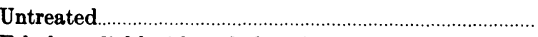 & 161 & 76.8 & 34.6 & 399 & 61.6 & 51.1 \\
\hline Ethylene dichloride, whole tubers & 45 & 68.9 & 30.2 & 106 & 73.0 & 44.3 \\
\hline Ethylene dichloride, cut sets & 30 & 96.7 & 33.2 & 96 & 51.0 & 47.6 \\
\hline Sodium nitrate, 0.5 mol. for 20 minutes & 77 & 78.3 & 29.0 & 203 & 69.0 & 42.1 \\
\hline 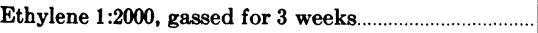 & 30 & 83.2 & 27.5 & 99 & 66.0 & 45.3 \\
\hline Propylene 1:2000, gassed for 3 weeks & 60 & 83.3 & 27.5 & 182 & 44.0 & 44.8 \\
\hline
\end{tabular}


permanganate at $0.02 \mathrm{~mol}$. concentration up to 30 minutes soaking proved to be mildly stimulating and non-toxic, but longer treatment or higher concentrations of this substance proved injurious in other tests. The permanganate is reduced rapidly by contact with cut potato sets.

In the summer of 1926 ethylene dichloride, sodium nitrate, ethylene and propylene were tested upon Idaho Rural tubers harvested nearly mature and stored for 24 days. The results are given in table 9 .

Ethylene dichloride was one of the substances which gave especially good results in Denny's experiments. In the tests here, it was used at the rate of 0.114 cc. to a liter of space, for 24 hours on whole tubers which were afterwards cut for planting, and half this dosage for 15 hours on cut sets. It proved to be moderately stimulating to sprouting but did not prevent the usual large percentage of seed piece decay. The same can be said for the other substances tested.

\section{Further Experiments with Ethylene Dichloride}

Further experiments were made in the summer of 1927 with ethylene dichloride upon Idaho Rural and Irish Cobbler. These two varieties had been previously found not to respond as vigorously to ethylene chlorhydrin as does the White Rose. The tubers used were harvested nearly mature and stored in a dry room at $22^{\circ}$ for three weeks before planting. They were, accordingly, well suberized at the time the treatments were made, which was two weeks after harvest and one week before planting. The treatment was by the vapor method, the proper amount of liquid ethylene dichloride being placed with the dry, whole tubers in a chamber which was kept closed for 24 hours. The tubers were of two classes, large tubers that were subsequently cut for planting, and tubers of one to one and one-half ounce weight, which were planted whole. The results are given in table 10

Considering first the effect of ethylene dichloride upon large tubers, it appears that there are no toxic effects with either of the concentrations used, since the percentage of stand is in all cases higher than in the untreated lots. It is also evident that this material exerts a marked stimulating effect upon both varieties tested. The evidence is not conclusive as to which concentration is most effective, but the higher concentration appears to be somewhat more so.

In the tests with small tubers planted whole, some increased stand resulted in every case, from treatment with ethylene dichloride, due 
TABLE 10

Effect of Ethylene Dichloride upon Sprouting of Cut Sets from Large Tubers, and of Small Whole Tubers. 1927

\begin{tabular}{|c|c|c|c|c|c|c|}
\hline & \multicolumn{3}{|c|}{ Coldframe planting } & \multicolumn{3}{|c|}{ Field planting } \\
\hline & $\begin{array}{c}\text { Number } \\
\text { of sets }\end{array}$ & $\begin{array}{l}\text { Per cent } \\
\text { stand }\end{array}$ & $\begin{array}{l}\text { Average } \\
\text { number of } \\
\text { days to } \\
\text { emerge }\end{array}$ & $\begin{array}{l}\text { Number } \\
\text { of sets }\end{array}$ & $\begin{array}{l}\text { Per cen } \\
\text { stand }\end{array}$ & $\begin{array}{l}\text { Average } \\
\text { number of } \\
\text { days to } \\
\text { emerge }\end{array}$ \\
\hline \multirow{4}{*}{ 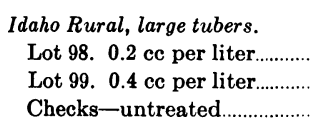 } & & & & & & \\
\hline & 30 & 83.3 & 43.8 & 97 & 75.3 & 42.2 \\
\hline & 30 & 96.7 & 25.5 & 111 & 68.5 & 31.2 \\
\hline & 90 & 57.7 & 35.6 & 554 & 56.5 & 37.9 \\
\hline \multicolumn{7}{|l|}{ Irish Cobbler, large tubers. } \\
\hline Lot $100.0 .2 \mathrm{cc}$ per liter & 30 & 100.0 & 30.8 & 115 & 83.5 & 24.1 \\
\hline Lot 101. 0.4 cc per liter & 30 & 96.7 & 29.1 & 115 & 81.7 & 26.8 \\
\hline Checks-untreated & 60 & 80.0 & 37.2 & 136 & 78.6 & 36.2 \\
\hline \multicolumn{7}{|l|}{ Idaho Rural, small tubers. } \\
\hline Lot 87.0 .2 cc per liter & 0 & .......... & .......... & 98 & 75.5 & 57.1 \\
\hline Lot 88. 0.4 cc per liter & 0 & .......... & .......... & 103 & 90.2 & 53.3 \\
\hline 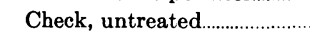 & 0 & $\ldots \ldots . .$. & ............. & 120 & 76.7 & 65.5 \\
\hline \multicolumn{7}{|l|}{ Irish Cobblers, small tubers. } \\
\hline Lot 93.0 .2 ce per liter & 0 & .......... & ......... & 100 & 88.0 & 48.3 \\
\hline Lot 94.0 .4 ce per liter................ & 0 & $\ldots \ldots . .$. & (n............ & 120 & 83.4 & 50.0 \\
\hline 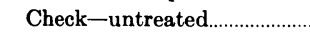 & 0 & .......... & ......... & 105 & 71.4 & 65.0 \\
\hline
\end{tabular}

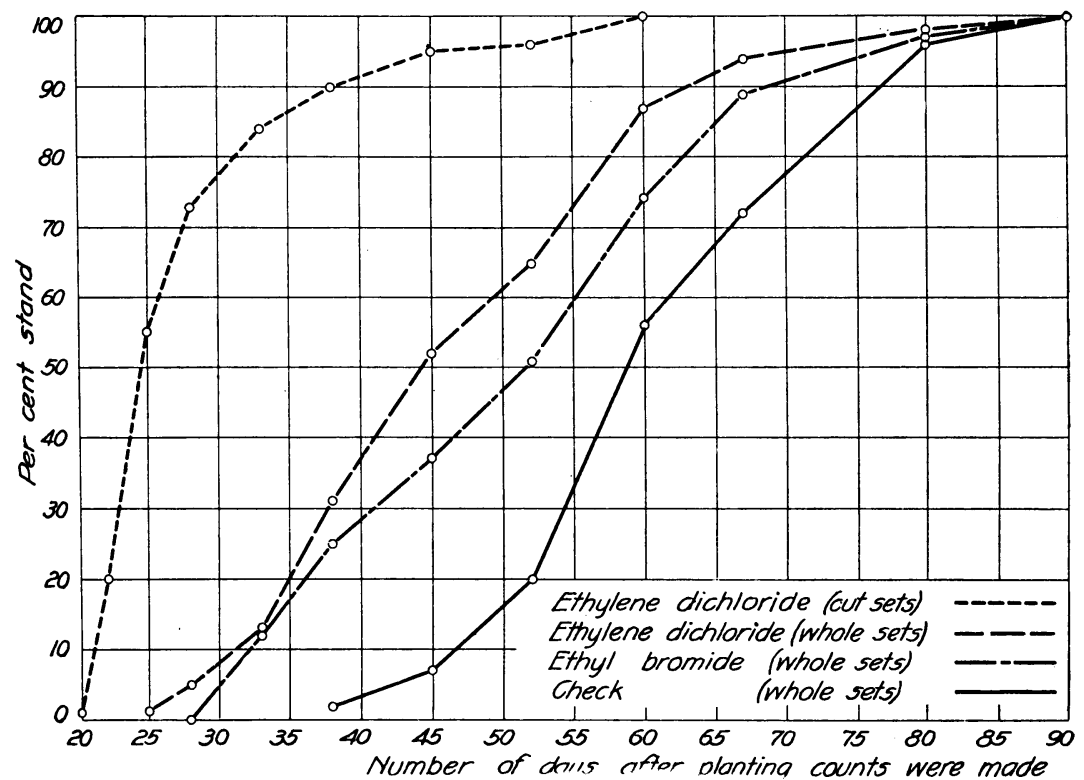

Fig. 2. The rate of sprout emergence of small tubers planted whole, untreated and after treatment with ethylene dichloride and ethyl bromide, compared to cut sets from large tubers treated with ethylene dichloride. Irish Cobbler variety. 
to the fact that more plants appeared above ground before the end of the growing season. Furthermore, there is some increase in the rate of sprouting, though here as in other experiments with tubers planted whole, the stimulatory effect is less than in tubers cut before planting. Whereas the treatment of large tubers reduced the average time required for emergence by about 30 per cent, with small whole sets this period was reduced only 15 per cent in Idaho Rural, and 26 per cent with Irish Cobbler. Figure 2 shows that whole tubers planted in the field, after treatment with ethylene dichloride and ethyl bromide, sprout more rapidly than untreated whole tubers, yet they lag considerably behind cut sets of the same variety.

\section{SUMMARY}

Ethylene, in concentrations of from 1:400 to 1:2200 of air, exerted a mild effect upon the hastening of sprouting of dormant, nearly matured, moderately suberized tubers placed in the gas chamber at harvest time and held there for four weeks.

Ethylene hastened the sprouting of fully matured White Rose tubers after treatment for only six days, while the Idaho Rural variety showed maximum stimulation after treatment for fifteen days.

Ethylene chlorhydrin proved to be a very effective material for treating the White Rose and Idaho Rural varieties, especially the former, at 14- and 21-day periods after harvest. Treatment with this material by the gas method on whole tubers and by soaking cut sets in a $1 / 2$ per cent solution for one hour, showed marked stimulation to sprouting without toxic effects. A third method, dipping cut sets in 3 per cent or stronger solutions for a moment, then storing over night in a closed container, resulted in a great increase in the decay of the sets after planting.

Treatment of large tubers with ethylene chlorhydrin by method 1 , at different stages during the storage period did not give consistently different results. With small tubers planted whole, however, the most marked stimulation effect was observed when the treatment was given at harvest time, when the tubers were only moderately suberized.

Tests to determine the optimum concentration of ethylene chlorhydrin to use according to method 1 , indicate that for large tubers that are well suberized, the most effective concentration is 0.75 cc. per liter of space. This is for treatment in a room at $20^{\circ}-25^{\circ} \mathrm{C}$, with a fan to hasten the volatilization of the gas, as well as to insure uniform distribution. 
Sodium thiocyanate and ammonium thiocyanate, especially the latter, were found to be toxic to cut sets soaked in 2 and 3 per cent solutions, when planted during hot weather. One per cent solution was non-toxic and had little or no stimulating effect.

Ethyl bromide was found to be an effective material for hastening sprouting, but the proper concentration for treatment varies widely, according to the maturity and degree of suberization of the tuber skin. This substance was not found to be satisfactory for the treatment of cut sets.

Sodium nitrate was moderately effective as a stimulant, when cut sets were soaked in an 0.5 mol. solution. However, this material is likely to cause excessive decay of the sets when the planting is made in hot weather.

Ethylene dichloride was very effective, especially on the Irish Cobbler variety, when used either as a gas on whole tubers or in solution for cut sets. The former method seems to be the most practical one. The optimum concentration probably lies between 0.2 and 0.4 cc. per liter of space, for a 24-hour exposure on large tubers.

Experiments with ethylene chlorhydrin, ethylene dichloride, and ethyl bromide upon small mature tubers that are planted whole, indicate that treatment of this class of tubers is much less effective than similar treatments upon large tubers that are cut before planting. It is not known whether this difference is due to a naturally longer and more profound dormancy in small tubers, or to the additive stimulation effect of cutting upon tubers previously treated with stimulants. From the practical viewpoint, however, of elimination of seed piece decay and of stimulating prompt sprouting of potatoes planted during midsummer, there is considerable promise for combinations of storage methods known to hasten sprouting with the use of chemical stimulants upon small tubers. 


\section{Literature Cited}

1 APPleman, C. O.

1914. Study of the rest period in potato tubers. Maryland Agr. Exp. Sta. Bul. 183:181-226.

2 DenNy, F. E.

1926. Hastening the sprouting of dormant potato tubers. Amer. Jour. Bot. 13:118-125.

3 Denny, F. E.

1926. Second report on the use of chemicals for hastening the sprouting of dormant potato tubers. Amer. Jour. Bot. 13:386-396.

4 McCallum, W. B.

1909. Ann. Report Arizona Agr. Exp. Sta. 11:584-586.

5 RosA, J. T.

1923 Abbreviation of the dormant period in potato tubers. Proc. Amer. Soc. Hort. Sci. 20:180-187.

6 Schlumberger, O.

1926. Die Kartoffel im Licht Physiologischer Forschung. Angew. Botanik. 8:262-274. 
The titles of the Technical Papers of the Californila Agriculitural Experiment Station, No8. 1 to 20, which HIICARDIA replaces, and copies of which may be had on application to the Publication Secretary, Agricultural Ixperimeast Station, Berkeley, are as follows:

1. The Removal of Sodium Carbonate from Solls, by Walter P. Kelley and Fdward E. Thomas. January, 1923.

8. The Formation of Sodium Oarbonate in Solls, by Arthur B. Cummins and Walter P. Kelley. March, 1923.

4. Iffect of Sodium Chlorid and Calcium Chlorid upon the Growth and Com. position of Young Orange Trees, by II, S. Reed and A. R. C. Haas. Aprill, 1923.

6. Oltrus Blast and Black PIt, by H. 8. Iawcett, W. T. Home, and A. I. Camp. May, 1923.

6. A Study of Deciduous Fruit Tree Rootstocks with Special Reference to Their Identification, by Myer J. Feppner. June, 1923.

7. A Study of the Darkening of Apple Ilssu6, by 7. I. Overholser and W. $\nabla$. Critess. June, 1923.

8. Fffect of Salts on the Intake of Inorganic Mlements and on the Buffer System of the Plant, by D. R. Hoagland and J. C. Martin. July, 1923.

9. Experiments on the Reclamation of Alkali solls by Ieaching with Water and Gypsum, by P. I. Fibbard. Angust, 1923.

10. The Seasonal Variation of the Soll Molsture in a Wainnt Grove in Relation to Hygroscopic Coefficient, by I. D. Batchelor and H. S. Reed. September, 1923.

11. Studies on the Bffects of Sodium, Potasstum, and Calcinm on Young Orange Trees, by I. S. Reed and A. B. C. Haas. October, 1923.

12. The Effect of the Plant on the Reaction of the Oulture Solution, by D. 2 . Hoagland. November, 1923.

13. Some Mutual Effects on Soll and Plant Induced by Added Solutes, by John B. Burd and J. C. Martin. December, 1923.

14. The Respiration of Potato Tubers in Relation to the Occurrence of Blackheart, by J. P. Bennett and B. T. Bartholomew. January, 1924.

15. Replaceable Bases in Solls, by Waiter P. Kolley and s. Malvin Brown. Fobruary, 1924.

16. The Molsture Equivalent as Influenced by the Amount of Soll Used in Its Determination, by $F$. J. Veihmeyer, O. W. Israelsen and J. P. Conrad. September, 1924.

17. Nutrient and Toxdc Effects of Certain Ions on Citrus and Walnut Trees with Especial Reference to the Concentration and $\mathrm{Ph}$ of the Medium, by II. 8. Reed and A. R. C. Haas. October, 1924 .

18. Factors Influencing the Rate of Germination of Seed of Asparagus offich nalis, by $\mathbf{E}$. A Borthwick. March, 1925.

19. The Relation of the Subcutaneous Administration of Iiving Bacterium abortum to the Immunity and Carrier Problem of Bovine Infectious Abortion, by George F. Hart and Jacob Traum. April, 1925.

20. A Study of the Condnctive Tissues in Shoots of the Bartlett Pear and the Belationship of Food Movement to Dominance of the Apical Buds, by Frank D. Cardner. Aprit, 1925. 